\title{
An alternative technique for septation of the aortopulmonary window using a fenestrated, unidirectional valved fabric patch
}

\author{
Ujjwal K. Chowdhury, MCh, Diplomate NB, Chander Mohan Mittal, MS, Anand K. Mishra, MCh, \\ Srikrishna M. Reddy, MS, Avneesh Sheil, MS, and Ganapathy K. Subramaniam, MCh, New Delhi, India
}

\begin{abstract}
Postoperative pulmonary hypertensive crises and right-sided heart failure remain the predominant cause of death in patients undergoing septation of the aortopulmonary window with moderate-to-severe pulmonary arterial hypertension (PAH). ${ }^{1,2}$ Although a unidirectional, fenestrated valved patch has been used in the setting of hypertensive atrial and ventricular septal defects to decompress the right-sided chambers in the event of pulmonary hypertensive crisis, there is no published report of aortopulmonary septation using this technique so far. ${ }^{3,4}$ We report the technique and results in 7 patients with a large aortopulmonary window with severe PAH using a fenestrated, unidirectional, valved polytetrafluoroethylene patch.
\end{abstract}

\section{CLINICAL SUMMARY}

Between January 1999 and December 2007, 7 patients underwent aortopulmonary window repair by a single surgeon using the surgical technique described after informed written consent and institutional ethics committee approval were obtained.

The demographic characteristics of all 7 patients are presented in Table 1. The diagnosis was established preoperatively by echocardiography, cardiac catheterization, and angiocardiography in all patients. Reversal of pulmonary vascular resistance (PVR) to 2.6 to 8.5 woods units $/ \mathrm{m}^{2}$ after oxygen (100\%) and nitric oxide (80 PPM) administration for 10 minutes suggested operability in all patients.

We used a transwindow approach to repair the aortopulmonary window by sandwich patch closure technique in these patients. On moderately hypothermic cardiopulmonary bypass, the right and left pulmonary arteries were temporarily snared and the heart was arrested using cold hyperkalemic blood cardioplegia. The anterior wall of the aortopulmonary window was opened vertically in between stay sutures. The defect was assessed, and the aortic and pulmonary valves were anatomically separated.

The unidirectional valve patch constructed from a polytetrafluoroethylene (WL Gore and Associates, Flagstaff, Ariz)

\footnotetext{
From the Department of Cardiothoracic Surgery, AIIMS, New Delhi, India.

Received for publication June 7, 2008; accepted for publication Sept 17, 2008; available ahead of print Dec 22, 2008.

Address for reprints: Ujjwal K. Chowdhury, MCh, Diplomate NB, Additional Professor, Department of Cardiothoracic and Vascular Surgery, All India Institute of Medical Sciences, New Delhi-110029, India (E-mail: ujjwalchow@rediffmail.com; ujjwalchowdhury@gmail.com).

J Thorac Cardiovasc Surg 2009;138:1433-5

$0022-5223 / \$ 36.00$

Copyright (C) 2009 by The American Association for Thoracic Surgery

doi:10.1016/j.jtcvs.2008.09.043
}

patch approximately as large as the defect, fenestrated with a 4-mm aortic punch, was used to close the defect in all patients. A quadrangular piece of untreated pericardium was attached by 6-0 Prolene suture to the surface of the polytetrafluoroethylene patch. The 3 edges of the pericardium were continuously sutured, and 1 edge was left unsutured. This unattached edge of pericardium will be functioning as a valve, the opening of which should not exceed $0.5 \mathrm{~cm}$ (Figure 1, $A-D$ ). The prosthetic patch is sewn to the superior, posterior, and inferior rim of the defect, avoiding occlusion of the coronary ostia and origins of the pulmonary arteries. The incision is subsequently closed interposing the patch in the anterior suture line.

After repair, patients were weaned from cardiopulmonary bypass in the usual manner. Postoperative management included continuous monitoring of pulmonary artery (PA) pressure and the use of ionodilators and pulmonary vasodilators isolated or in combination. After 24 hours, all patients had a paroxysmal pulmonary hypertensive crisis that was treated accordingly. Echocardiography during the period of pulmonary hypertensive crisis demonstrated a perfectly positioned aorticopulmonary partition, right-to-left shunting through the fenestration in all, clearly documenting its role as temporary valved vent. Serial echocardiography revealed normalization of PA pressure by the tenth to fifteenth day with gradual closure of the unidirectional valve and improved hemodynamics.

There were no early or late deaths on follow-up visit ranging from 18 to 120 months (median 71 months). All patients are in New York Heart Association class I with $\mathrm{SaO}_{2}$ ranging from $94 \%$ to $98 \%$ (median, 96\%) at their last follow-up visit, and none required anti-failure medications. Twodimensional Doppler echocardiogram and computed tomographic angiography revealed normal biventricular function and absence of flow through the fenestrated aorticopulmonary septum without any distortion of aortic and pulmonary root structures and right and left pulmonary arterial origins.

\section{DISCUSSION}

The safe upper limit of PA pressure and PVR in patients with aortopulmonary window undergoing surgical correction remains unclear. Consensus exists that surgical closure of the aortopulmonary window should not be performed when the PVR is more than 10 Woods Units, the ratio of pulmonary to systemic flow (QP/QS) is less than 1.5 , the pulmonary-to-systemic vascular resistance ratio is greater than 0.7 , and the $\mathrm{SaO}_{2}$ less than $90 \%$. $^{1-4}$

Several investigators have demonstrated a variable relationship among PA muscularity, pressure, and resistance 
TABLE 1. Demographic data, cardiac anatomy, type of operation, and results of patients under study

\begin{tabular}{|c|c|c|c|c|c|c|c|}
\hline $\begin{array}{l}\text { Patient } \\
\text { No. }\end{array}$ & Age & Sex & $\begin{array}{l}\text { Weight } \\
\text { (kg) }\end{array}$ & Diagnosis & Preoperative catheterization data & Operation & Results \\
\hline 1. & $1 \mathrm{mo}$ & Female & 5.0 & $\begin{array}{l}\text { Aortopulmonary } \\
\text { window (type I) }\end{array}$ & $\begin{array}{c}\mathrm{PAP}(\mathrm{mm} \mathrm{Hg}) \mathrm{S} / \mathrm{D}=90 / 18, \mathrm{M}=42 \mathrm{~mm} \\
\mathrm{Hg} \mathrm{SPAP} / \mathrm{SABP}=1.0 \mathrm{PVR} \text { (room air) } \\
=4.8 \mathrm{wu} / \mathrm{m}^{2} \mathrm{PVR}(100 \% \text { oxygen }+ \\
\mathrm{NO})=2.6 \mathrm{wu} / \mathrm{m}^{2} \mathrm{SaO}_{2} 97 \%\end{array}$ & $\begin{array}{l}\text { Fenestrated, valved, } \\
\text { aortopulmonary } \\
\text { partition }\end{array}$ & $\begin{array}{c}\text { Alive and well } \\
\text { at } 120 \mathrm{mo}\end{array}$ \\
\hline 2 & $2 \mathrm{mo}$ & Male & 6.0 & $\begin{array}{l}\text { Aortopulmonary } \\
\text { window (type I) }\end{array}$ & $\begin{array}{c}\mathrm{PAP}(\mathrm{mm} \mathrm{Hg}) \mathrm{S} / \mathrm{D}=96 / 28, \mathrm{M}=51 \mathrm{~mm} \\
\mathrm{Hg} \mathrm{SPAP} / \mathrm{SABP}=1.2 \mathrm{PVR} \text { (room air) } \\
=5.2 \mathrm{wu} / \mathrm{m}^{2} \mathrm{PVR}(100 \% \text { oxygen }+ \\
\mathrm{NO})=3.0 \mathrm{wu} / \mathrm{m}^{2} \mathrm{SaO}_{2} 96 \%\end{array}$ & $\begin{array}{l}\text { Fenestrated, valved, } \\
\text { aortopulmonary } \\
\text { partition }\end{array}$ & $\begin{array}{c}\text { Alive and well } \\
\text { at } 106 \mathrm{mo}\end{array}$ \\
\hline 3 & $10 \mathrm{mo}$ & Male & 7.2 & $\begin{array}{l}\text { Aortopulmonary } \\
\text { window (type I) }\end{array}$ & $\begin{array}{l}\mathrm{PAP}(\mathrm{mm} \mathrm{Hg}) \mathrm{S} / \mathrm{D}=110 / 36, \mathrm{M}=57 \\
\mathrm{~mm} \mathrm{Hg} \mathrm{SPAP} / \mathrm{SABP}=1.2 \mathrm{PVR} \\
(\text { room air })=9.0 \mathrm{wu} / \mathrm{m}^{2} \mathrm{PVR}(100 \% \\
\text { oxygen }+\mathrm{NO})=5.0 \mathrm{wu} / \mathrm{m}^{2} \mathrm{SaO}_{2} 92 \%\end{array}$ & $\begin{array}{l}\text { Fenestrated, valved, } \\
\text { aortopulmonary } \\
\text { partition }\end{array}$ & $\begin{array}{c}\text { Alive and well } \\
\text { at } 94 \mathrm{mo}\end{array}$ \\
\hline 4 & $8 \mathrm{y}$ & Male & 16 & $\begin{array}{l}\text { Aortopulmonary } \\
\text { window (type II) }\end{array}$ & $\begin{array}{l}\mathrm{PAP}(\mathrm{mm} \mathrm{Hg}) \mathrm{S} / \mathrm{D}=116 / 32, \mathrm{M}=60 \\
\mathrm{~mm} \mathrm{Hg} \mathrm{SPAP} / \mathrm{SABP}=1.4 \mathrm{PVR} \\
(\text { room air })=16.0 \mathrm{wu} / \mathrm{m}^{2} \mathrm{PVR}(100 \% \\
\text { oxygen }+\mathrm{NO})=7.0 \mathrm{wu} / \mathrm{m}^{2} \mathrm{SaO}_{2} 92 \%\end{array}$ & $\begin{array}{l}\text { Fenestrated, valved, } \\
\text { aortopulmonary } \\
\text { partition }\end{array}$ & $\begin{array}{l}\text { Alive and well } \\
\text { at } 71 \mathrm{mo}\end{array}$ \\
\hline 5 & $19 \mathrm{y}$ & Male & 36 & $\begin{array}{l}\text { Aortopulmonary } \\
\text { window (type I) }\end{array}$ & $\begin{array}{l}\mathrm{PAP}(\mathrm{mm} \mathrm{Hg}) \mathrm{S} / \mathrm{D}=124 / 38, \mathrm{M}=66 \\
\mathrm{~mm} \mathrm{Hg} \mathrm{SPAP} / \mathrm{SABP}=1.6 \mathrm{PVR} \\
(\text { room air })=14.0 \mathrm{wu} / \mathrm{m}^{2} \mathrm{PVR}(100 \% \\
\text { oxygen }+\mathrm{NO})=8.2 \mathrm{wu} / \mathrm{m}^{2} \mathrm{SaO}_{2} 92 \%\end{array}$ & $\begin{array}{l}\text { Fenestrated, valved, } \\
\text { aortopulmonary } \\
\text { partition }\end{array}$ & $\begin{array}{c}\text { Alive and well } \\
\text { at } 60 \mathrm{mo}\end{array}$ \\
\hline 6 & $20 \mathrm{y}$ & Male & 48 & $\begin{array}{l}\text { Aortopulmonary } \\
\text { window (type I) }\end{array}$ & $\begin{array}{l}\mathrm{PAP}(\mathrm{mm} \mathrm{Hg}) \mathrm{S} / \mathrm{D}=118 / 28, \mathrm{M}=58 \\
\mathrm{~mm} \mathrm{Hg} \mathrm{SPAP} / \mathrm{SABP}=1.6 \mathrm{PVR} \\
(\text { room air })=18.0 \mathrm{wu} / \mathrm{m}^{2} \mathrm{PVR}(100 \% \\
\text { oxygen }+\mathrm{NO})=8.5 \mathrm{wu} / \mathrm{m}^{2} \mathrm{SaO}_{2} 94 \%\end{array}$ & $\begin{array}{l}\text { Fenestrated, valved, } \\
\text { aortopulmonary } \\
\text { partition }\end{array}$ & $\begin{array}{c}\text { Alive and well } \\
\text { at } 46 \mathrm{mo}\end{array}$ \\
\hline 7 & $23 \mathrm{y}$ & Female & 50 & $\begin{array}{l}\text { Aortopulmonary } \\
\text { window (type I), } \\
\text { subaortic stenosis }\end{array}$ & $\begin{array}{l}\mathrm{PAP}(\mathrm{mm} \mathrm{Hg}) \mathrm{S} / \mathrm{D}=116 / 36, \mathrm{M}=62 \\
\mathrm{~mm} \mathrm{Hg} \mathrm{SPAP} / \mathrm{SABP}=1.6 \mathrm{PVR} \\
\quad(\text { room air })=18.0 \mathrm{wu} / \mathrm{m}^{2} \mathrm{PVR}(100 \% \\
\text { oxygen }+\mathrm{NO})=8.0 \mathrm{wu} / \mathrm{m}^{2} \mathrm{LV} \text { to } \\
\text { aortic gradient }=40 \mathrm{~mm} \mathrm{Hg} \mathrm{SaO} 288 \%\end{array}$ & $\begin{array}{l}\text { Fenestrated, valved, } \\
\text { aortopulmonary } \\
\text { partition, resection } \\
\text { of subaortic } \\
\text { membrane }\end{array}$ & $\begin{array}{c}\text { Alive and well } \\
\text { at } 18 \mathrm{mo}\end{array}$ \\
\hline
\end{tabular}

$L V$, Left ventricle; $N O$, nitric oxide; $P A P$, pulmonary artery pressure; $P V R$, pulmonary vascular resistance; $S / D / M$, systolic, diastolic, mean; $S P A P$, systolic pulmonary artery pressure; $S A B P$, systolic arterial blood pressure.

in different types of congenital heart diseases and addressed the difficulties inherent in using a grading system to evaluate the severity of the disease and prediction of operative outcome. ${ }^{5}$ In practice, therefore, it is difficult to identify the proportion of late presenters of septal defects with severe PAH who will have a protected pulmonary vascular bed before biventricular repair.

One important finding of our investigation given their age at surgery is the occurrence of suprasystemic PA pressure in the postoperative period in all patients with unstable hemodynamics despite optimal perioperative management. During episodes of pulmonary hypertensive crises, the fenestrated, valved, aorticopulmonary septum acted as a temporary "pop-off" valve, permitted right-to-left shunting, increasing left ventricular preload and cardiac output, albeit at the expense of some degree of systemic desaturation. Our initial concern was the possibility of excessive shunt across the fenestration because of its location within the great arteries. To address these concerns, the pericardial flap should be placed on the left side (systemic) of the defect with the opening of the unattached edge of the pericardium should not exceed $0.5 \mathrm{~cm}$ and appropriate tension should be maintained on the pericardial edge, so that the valve mechanism is neither too loose and incompetent nor too tight to lose its valve effectiveness.

It is conceivable that the unidirectional valve will close and block the shunt once the PA pressure normalizes. Our study demonstrated early normalization of PA pressure, indicating that pulmonary hypertension was mostly reactive. Therefore, this series does not allow evaluation of longterm clinical outcome of this device. Second, this technique obliges one to use a transwindow technique with a single patch, which can lead to leaks or distortion of the branch pulmonary arteries, especially in infants and neonates.

\section{CONCLUSIONS}

The use of a 1-way, valved aorticopulmonary septal patch as part of the surgical repair may allow decompression of the right-sided chambers in the event of perioperative pulmonary hypertensive crises, thus preventing postoperative right-sided heart failure. This technique further improves the surgical results without having to resort to reintervention 

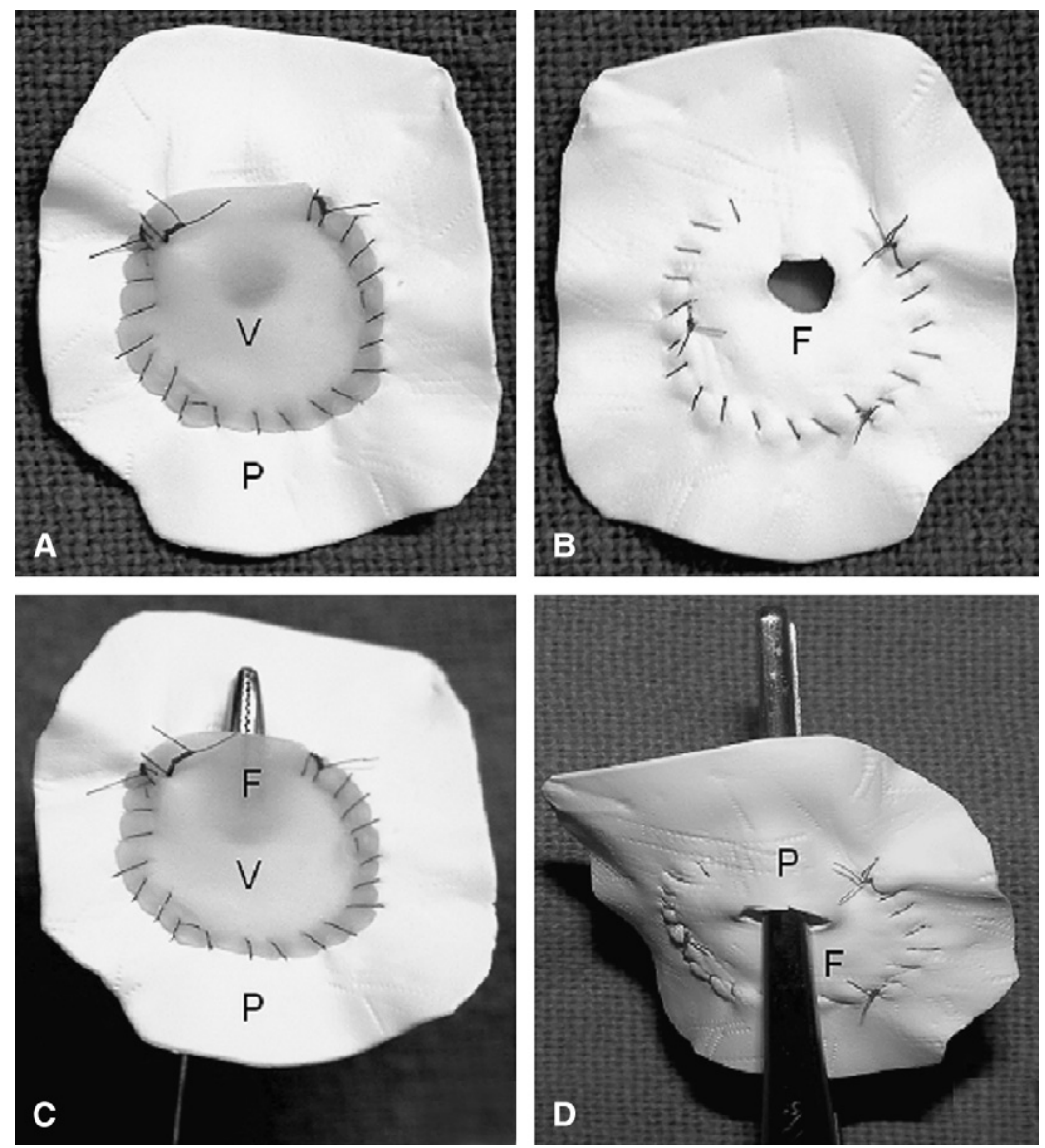

FIGURE 1. Construction of the unidirectional, fenestrated, valved, aorticopulmonary patch to be used for aortopulmonary septation of the aortopulmonary window. A, View from the aortic side of the septum. A 4-mm fenestration is created in the center of the polytetrafluoroethylene patch. Three sides of the pericardial patch are attached, and 1 side is left open to function as a valve measuring up to $0.5 \mathrm{~cm}$ away from the fenestration. B, View from the pulmonary arterial side of the septum showing the fenestration and suture line. C, View from the aortic side showing the tip of an artery forceps through the fenestration and the unattached pericardial patch. D, View from the pulmonary arterial side showing the valvular mechanism to allow blood to flow only from the PA to aorta, when the PA pressure turns suprasystemic. $F$, Fenestration; $V$, valve; $P$, patch.

for closure of fenestration once the reactive components of pulmonary hypertension disappear.

\section{References}

1. Jansen C, Hruda J, Rammeloo L, et al. Surgical repair of aortopulmonary window: Thirty seven years of experience. Pediatr Cardiol. 2006;27:552-6.

2. Backer CL, Mavroudis C. Surgical management of aortopulmonary window: a 40-year experience. Eur J Cardiothorac Surg. 2002;21:773-9.
3. Ad N, Birk E, Barak J, Diamant S, Snir E, Vidne RA. A one-way valved atrial septal patch: a new surgical technique and its clinical application. J Thorac Cardiovasc Surg. 1996;111:841-8.

4. Zhou Q, Lai Y, Wei H, Song R, Wu Y, Zhang H. Unidirectional valve patch for repair of cardiac septal defects with pulmonary hypertension. Ann Thorac Surg. 1995;60:1245-9.

5. Rabinovich M, Keane JF, Norwood WI, Castaneda AR, Reid L. Vascular structure in lung tissue obtained at biopsy correlated with pulmonary hemodynamic findings after repair of congenital heart defects. Circulation. 1984;69: 655-67. 